\title{
Appeal of Christians and the People of Good Will in Poland for the Care of Creation
}

\author{
(May 16, 2019)
}

The earth is the Lord's and all that is in it,
the world, and those who live in it.
Ps 24:1
G athered on $16^{\text {th }}$ May 2019 at the conference "Church towards the ecological crisis", organised on the $3 \mathrm{O}^{\text {th }}$ anniversary of the Polish Bishops' pastoral letter dedicated to environment protection, we speak on behalf of the circles of intellectuals, businessmen, non-governmental organisations, government and local government administration, media, religious communities and students we represent. Being aware of the challenges humanity faces today, we are convinced of the necessity of joining all people's efforts to care for the Earth - a safe place to live for present and future generations.

We, Christians and all the people of good will, aware of our responsibility, turn to those, whose duties make them responsible for the state of the environment, as well as all those care about the well-being of all members of the earthly community of life, to take concrete action to protect our earthly heritage. Being aware of the differences between us, we are making a joint appeal for commitment to care for the world around us. As Christians we share many motivations of our non-believing sisters and brothers, who care for the nature - for the sake of the nature itself, as well as for the sake of humans. Our motivations, however, reach to our faith, which commands us to manage responsibly the heritage entrusted to us by the Creator. Although God has distinguished man from all creatures and let him "subdue" the Earth and "have dominion over the fish of the sea and over the birds of the air and over every living thing that moves upon the earth" (Gen 1:28), He also held him responsible for the legacy entrusted to him (Gen 2:15). He confirmed this by establishing a covenant not only with man, but with all other living beings (Gen 9:9-10). Ultimately, the Creator left no doubt that the Earth is His property and that man is only its steward ( $\left.{ }_{1} \mathrm{Chr} 29: 11\right)$. If man fails to care for it, he will meet an inevitable punishment (Rev 11:18). In addition, God assured-during the messianic times-that He would establish a new covenant with all creation (Ho 2:20) and restore the original harmony between man and nature (Is 11:6-9).

We, Christians, aware that nature itself worships the Creator (Ps 148; Dn 3:57-81) and encourages us to do the same (Sir 43:11), feel a great responsibility for the world around us. At the same time, we are aware, that often we go against the commandments of the Creator by not showing due respect to the nature and by using it selfishly and 
irresponsibly, making creation groan (Rom 8:22). In reference to this passage, Pope Francis says that "to commit a crime against the natural world is a sin against ourselves and a sin against God" (Laudato $s i$ : No. 8). Christians are therefore obliged to ecological conversion, which manifests itself in breaking with the sin against nature (Laudato si': No. 216-221).

We are also aware, that for the regulations of nature conservation to be sufficiently effective, they should be reinforced by actions driven by religious motives. We are convinced, that such actions will positively affect the overcoming of the ecological crisis. For this reason, we turn to our Christian sisters and brothers and all the people of good will to make individual and joint efforts leading to climate protection, saving natural resources, avoiding food waste and litter, responsible consumption, caring for the greenery around our homes, respect for the animals, public transport preference and other forms of reducing pollution and minimizing the negative human footprint on the environment, as well as caring for the most needy, whom are not only the currently living people and other living beings, but also the future inhabitants of the Earth. At the same time, we share Pope Francis' optimism, that with the help of the Creator, man is able to overcome his egoism and build a more just world, which will be a safe home for all creation.

The signatories of this appeal encourage the debate on practical ways of implementing this message and the dissemination of its content in various environments. 